Article

\title{
Performance Evaluation of Tight Ultrafiltration Membrane Systems at Pilot Scale for Agave Fructans Fractionation and Purification
}

\author{
Noe Luiz-Santos ${ }^{1}$, Rogelio Prado-Ramírez ${ }^{1, *}$, Enrique Arriola-Guevara ${ }^{2}$, \\ Rosa-María Camacho-Ruiz $^{1}$ (D) and Lorena Moreno-Vilet ${ }^{3, * \mathbb{D}}$ \\ 1 Centro de Investigación y Asistencia en Tecnología y Diseño del Estado de Jalisco A.C. Camino arenero 1227. \\ El Bajío, C.P. 45019 Zapopan, Jalisco, Mexico; noeibq24@gmail.com (N.L.-S.); rcamacho@ciatej.mx (R.-M.C.R.) \\ 2 Departamento de Ingeniería Química, CUCEI-Universidad de Guadalajara, Blvd. M. García Barragán 1421, \\ C.P. 44430 Guadalajara, Jalisco, Mexico; arriole@hotmail.com \\ 3 CONACYT- Centro de Investigación y Asistencia en Tecnología y Diseño del Estado de Jalisco A.C. Av. \\ Normalistas 800, Colinas de la Normal, C.P. 44270 Guadalajara, Jalisco, Mexico \\ * Correspondence: rprado@ciatej.mx (R.P.-R.); lmoreno@ciatej.mx (L.M.-V.)
}

Received: 29 August 2020; Accepted: 21 September 2020; Published: 27 September 2020

\begin{abstract}
Ceramic and polymeric membrane systems were compared at the pilot scale for separating agave fructans into different molecular weight fractions that help to diversify them into more specific industrial applications. The effect of the transmembrane pressure of ultrafiltration performance was evaluated through hydraulic permeability, permeate flux and rejection coefficients, using the same operating conditions such as temperature, feed concentration and the molecular weight cut-off (MWCO) of membranes. The fouling phenomenon and the global yield of the process were evaluated in concentration mode. A size distribution analysis of agave fructans is presented and grouped by molecular weight in different fractions. Great differences were found between both systems, since rejection coefficients of $68.6 \%$ and $100 \%$ for fructans with degrees of polymerization (DP) $>10$, $36.3 \%$ and $99.3 \%$ for fructooligosaccharides (FOS) and $21.4 \%$ and $34.2 \%$ for mono-disaccharides were obtained for ceramic and polymeric membrane systems, respectively. Thus, ceramic membranes are better for use in the fractionation process since they reached a purity of $42.2 \%$ of FOS with a yield of $40.1 \%$ in the permeate and $78.23 \%$ for fructans with DP > 10 and a yield of $70 \%$ in the retentate. Polymeric membranes make for an efficient fructan purification process, eliminating only mono-disaccharides, and reaching a $97.7 \%$ purity (considering both fructan fractions) with a yield of $64.3 \%$ in the retentate.
\end{abstract}

Keywords: fine ultrafiltration; agave fructans; ceramic membrane; polymeric membrane; rejection coefficient

\section{Introduction}

Native agave fructans are a heterogeneous mixture of branched fructose polymers, linked by glycosidic linkages of fructose-fructose $\beta(2-1)$ and $\beta(2-6)$, with intermediate or terminal glucose units with degrees of polymerization (DP) between three and 29 [1]. These fructans have potential applications due to their proven beneficial effects on human health, such as the prebiotic effect, as well as decreasing the body mass index, total body fat and triglyceride levels [2-5] and their technological applications as encapsulating agents and as substitutes for fat in food [6-10]. However, it has been reported that fructans with different DP differ in their prebiotic effectiveness and techno-functional properties, as well as in the removal of low-molecular weight sugars such as glucose, fructose and sucrose, increasing the purity and functionality of fructans. For example, the fraction of agave fructans 
with DP > 10 improves the biological effect of triglyceride reduction in relation to native fructans, while the enriched fraction of fructooligosaccharides (FOS) enhances the decrease in body weight, body fat, hyperglycemia and hepatic steatosis [11-13]. For these reasons, the membrane process has been proposed to obtain agave fructans with a higher purity [14-16] and to obtain different DP fractions $[17,18]$.

The ultrafiltration (UF) process uses a membrane as a selective barrier according to its molecular weight cut-off (MWCO) in the range from 1 to $300 \mathrm{kDa}$ [19], where the sieving effect dominates the UF process when using membranes with an MWCO greater than $4 \mathrm{kDa}$. However, separation using tight UF membranes (from 1 to $3 \mathrm{kDa}$ ) becomes more complex because it combines the sieving effect and Donnan exclusion, like the phenomenon that dominates the nanofiltration process (from $200 \mathrm{Da}$ to $1 \mathrm{kDa}$ ). In some cases, the membrane with $1 \mathrm{kDa}$ MWCO is considered a nanofiltration membrane because it is at the cut-off limit and is used for decolorization, phosphate elimination, and the purification of oligosaccharides [14,20-22].

The information given by the suppliers is limited to the MWCO, which is defined as the molecular weight (MW) at which $90 \%$ of the solute is rejected by the membrane; however, there is no standardized procedure for this test, so there could be variability under different conditions [23]. Furthermore, rejection is affected by the molecular shape of the solute, the membrane-solute interaction, the configuration of the membrane, and the interaction between the solutes and the concentration polarization phenomenon, which can reduce the size of the pores and affect the separation [24,25].

In addition to the above, choosing the membrane configuration and its material is crucial for each application, since it depends on obtaining good separation and yields. Currently, polymeric membranes have a greater application in the industry; however, ceramic membranes have gained interest in recent years. It is important to realize that each system has advantages and disadvantages, depending on the application. In this sense, polymeric membranes are more sensitive to temperature and $\mathrm{pH}$ conditions in cleaning cycles. Proper cleaning and maintenance can allow polymer membranes to be replaced every 1.5 years, while ceramic membranes can have a lifespan of approximately 7 years [26]. From the economic-commercial perspective, the cost of installing a ceramic membrane is $80-90 \%$ higher than that corresponding to a polymeric membrane, while, in terms of membrane prices, the ratio is approximately $4: 1[27,28]$. It is important to mention that membrane fouling is of great concern for the application of membrane technology [29-34], which is reflected in the flux decrease resulting from the clogging of the membrane pore, which can be an irreversible phenomenon in some cases. The information generated in the experimental evaluation is necessary for the implementation of a successful separation process [28].

Thus, in order to choose the right system, some authors have studied the comparison between ceramic and polymeric membranes for different purposes and applications [35-38]. Few studies have been carried out using the same membrane cut-off and the same operating conditions $[39,40]$ and none have been applied to agave fructan fractionation. The industry must define the purification and fractionation process for agave fructans and, for these reasons, the objective of this study was to comparatively evaluate the operation of ceramic and polymeric membrane systems at the pilot scale in the tight UF process of agave fructans, in terms of their hydraulic permeability, permeate flux, rejection coefficient, fouling resistance and the global yield of the process.

\section{Materials and Methods}

\subsection{Agave Fructans}

The aqueous solution of $10 \mathrm{~kg} \cdot \mathrm{m}^{-3}$ Agave tequilana fructans (Olifructine ${ }^{\circledR}$ ) was prepared from syrup at $70 \mathrm{~kg} \cdot \mathrm{m}^{-3}$, which was kindly provided by Nutriagaves de Mexico (Jalisco, Ayotlan, Mexico). 


\subsection{Pilot Scale Filtration System and Membranes}

A crossflow pilot-scale filtration unit (original design) was used to carry out all experiments (Figure 1). The system is equipped with a $0.15 \mathrm{~m}^{3}$ tank, and an interchangeable membrane module to exchange polymeric and ceramic membranes. The feed flow to the membrane was driven by a centrifugal pump and a positive displacement pump (10SV, Gould, Lake Mary, FL, USA) connected in series. The system had flow, pressure and temperature sensors connected to a programmable logic controller (PLC) with a digital panel display to monitor and control the operational parameters. To reach the operating temperature, a heat exchanger placed before the membrane module was used. The operating pressure was manually adjusted with valves in permeate and retentate line streams.

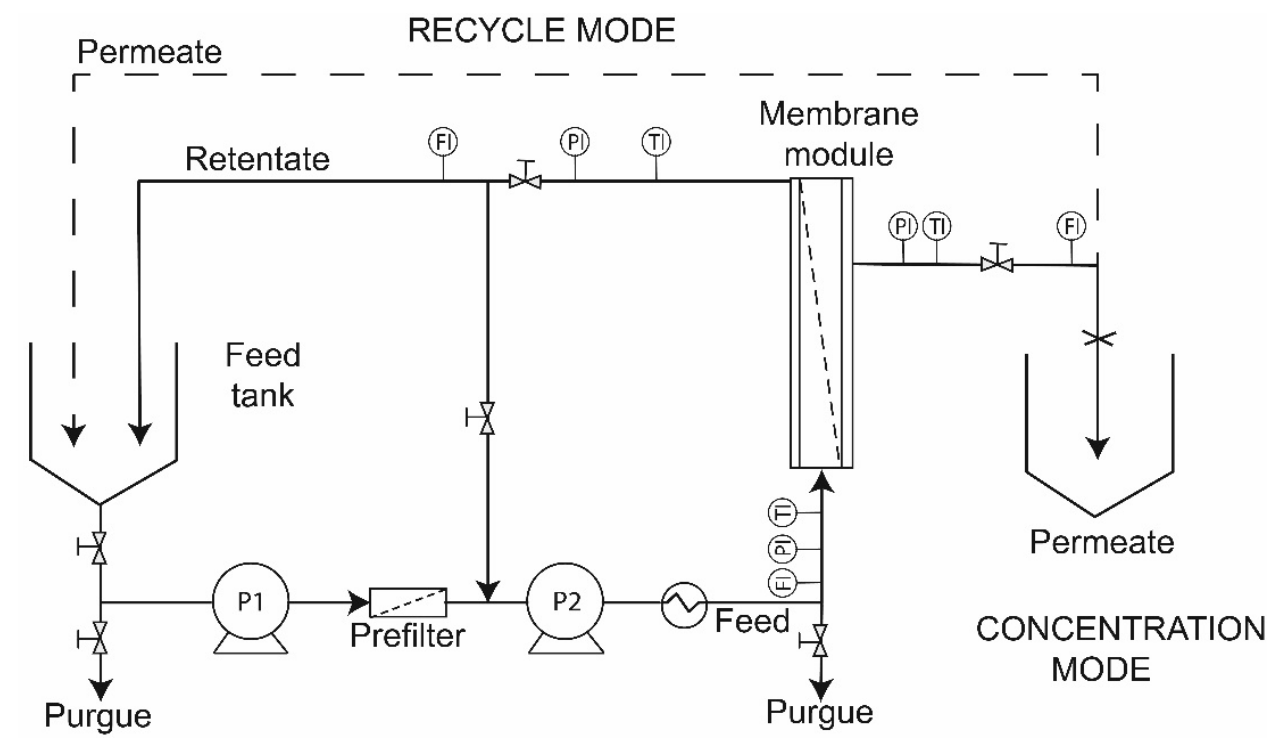

Figure 1. Schematic diagram of the ultrafiltration pilot scale unit used. P1: centrifugal pump; P2: positive displacement pump; TI: Temperature Indicator; PI: Pressure Indicator; FI: Flow Rate Indicator.

To compare the ceramic and polymeric membrane systems, new membranes were used for the experiments-a 39-channel ceramic membrane (inside-Céram, TAMI Industries, Les Laurons, Nyons, France) and a spiral polymeric membrane (Hydracore 50, Hydranautics Company, Oceanside, CA, USA) with the same MWCO of $1 \mathrm{kDa}$ (Figure 2). The characteristics of these membranes are shown in Table 1.

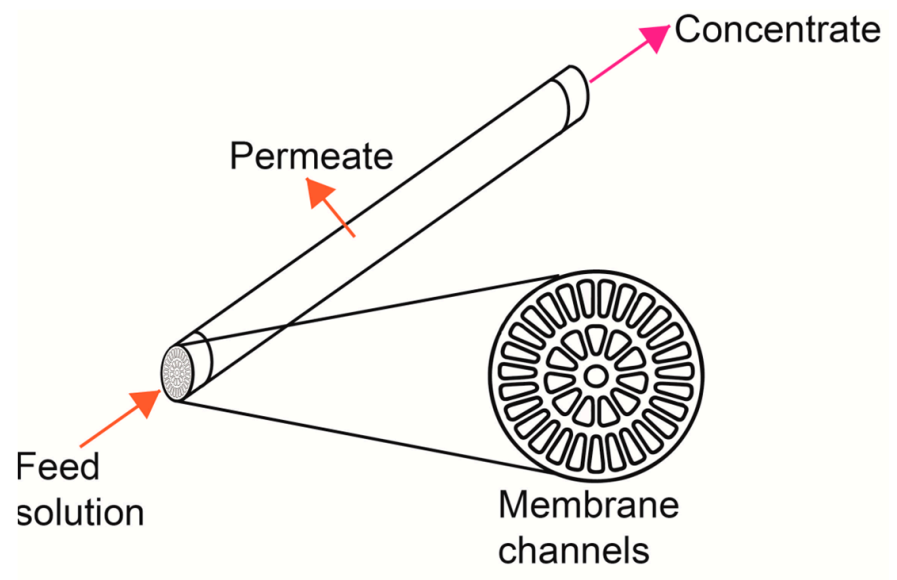

(a)

Figure 2. Cont. 


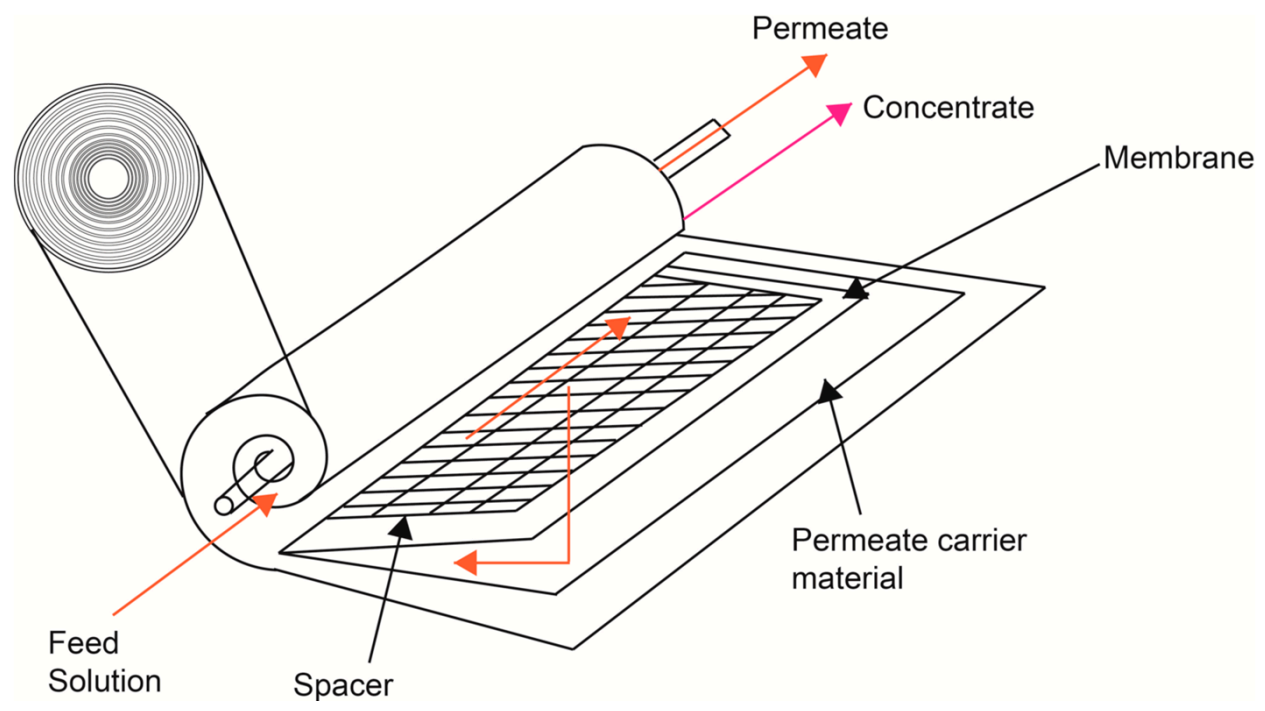

(b)

Figure 2. Schematic diagram of tubular ceramic membrane (a) and polymeric spiral-wound membrane (b).

Table 1. Characteristics of tight ultrafiltration membranes used.

\begin{tabular}{ccc}
\hline Specification & Ceramic Membrane & Polymeric Membrane \\
\hline Manufacturer & Tami industries & Hydranautics Nitto Group Company \\
Material & Zirconium/titanium dioxide & Sulfonated polyethersulfone \\
Configuration & Tubular & Spiral \\
Molecular weight cut-off & $1 \mathrm{kDa}$ & $1 \mathrm{kDa}$ \\
Membrane area & $0.5 \mathrm{~m}^{2}$ & $7.4 \mathrm{~m}^{2}$ \\
Operating pressure & $<100 \times 10^{5} \mathrm{~Pa}$ & $<41 \times 10^{5} \mathrm{~Pa}$ \\
Operating pH & $0-14$ & $2-11$ \\
Operating temperature & $<350^{\circ} \mathrm{C}$ & $<50^{\circ} \mathrm{C}$ \\
Spacer height & $\mathrm{NA}$ & $8.63 \times 10^{-4} \mathrm{~m}^{*}$ \\
Spacer porosity & $\mathrm{NA}$ & $0.89^{*}$ \\
Mean pore radio $(\mathrm{nm})$ & $3^{* *}$ & $2.12^{* * *}$ \\
\hline
\end{tabular}

$*[41], * *[42],{ }^{* * *}[43]$.

\subsection{Measurement of Size Distribution of Fructans}

The size distribution of fructans at initial, retentate and permeate streams was analyzed by HPLC-size exclusion chromatography (SEC), using a 1220 Infinity LC System for HPLC coupled with a refractive index detector (Agilent, Alpharetta, GA, USA) and an Ultrahydrogel DP column and guard column (7.8 mm d.i. $\times 300 \mathrm{~mm}$, Waters, Milford, MA, USA) in the stationary phase, according to the methodology proposed by Moreno-Vilet et al. (2017) [44]. This technique allowed us to obtain a relative abundance of fructans separated in three groups or fractions for practical purposes: fructans with DP $>10(\mathrm{Fc})$, FOS with DP between 3 and 10 and mono-disaccharides (MD) with DP of 1-2, such as glucose, fructose and sucrose.

\subsection{Evaluation of Membrane Systems Performance}

The carbohydrate separation process for each membrane system (ceramic and polymeric) was evaluated in total recycle and concentration modes. The total recycle mode was first carried out in order to compare both membrane systems in terms of permeate flux and selectivity (based on the rejection coefficient). The above means that the permeate and retentate streams of the UF pilot unit were returned to the feed tank at adjusted conditions until reaching a steady state, when the permeate flux and Total Soluble Solids (TSS) did not vary with time; at that moment, the sampling and measurements 
were carried out. The permeate flux was measured and samples of the permeate and concentrate were collected at $1 \times 105,3 \times 105$ and $5 \times 105 \mathrm{~Pa}$ of transmembrane pressure $(\mathrm{TMP})$. The system was operated in batches in concentrations of $10 \mathrm{~kg} \cdot \mathrm{m}^{-3}$ of aqueous extract because it is the usual concentration of agave juices after extraction in industrial diffusers $[45,46]$. A temperature of $318 \mathrm{~K}$ and a feed flow of $1.8 \mathrm{~m}^{3} \cdot \mathrm{h}^{-1}$ were chosen based on our previous experience and on recommendations by Flores Montaño et al. (2015) [18].

Once the operating conditions were selected, experiments were carried out in concentration mode under the same conditions of temperature, TMP and $0.1 \mathrm{~m}^{3}$ feed concentration at $10 \mathrm{~kg} \cdot \mathrm{m}^{-3}$ for both membrane systems. These experiments permitted us to quantify the overall yield and purification of each carbohydrate fraction, as well as to quantify the fouling phenomenon. The system was operated in batch mode, where the permeate stream was collected in a tank and the retentate stream was recycled to a feed tank. The volume reduction factor (VRF) was calculated as the ratio between the initial feed volume $\left(V_{f}\right)$ and the retentate volume $\left(V_{r}\right)$ at any given time (Equation (1)). Samples of the permeate stream were collected for the HPLC-SEC analysis at VRF values of 1.11, 1.25, 1.42, 1.66, 2 and 2.5.

$$
V R F=\frac{V_{f}}{V_{r}}
$$

\subsubsection{Water Permeability and Permeate Flux}

The water permeability $\left(L_{p}\right)$ was measured before and after each experiment to calculate the resistances of the fouling phenomena. First, the membranes were cleaned with demineralized water for about $2-3 \mathrm{~h}$ to remove any residual sodium metabisulfite. The pure water permeability was obtained from the slope of the permeate flux as a function of TMP using Equation (2).

$$
J_{w}=\frac{T M P}{\mu_{w} \cdot R_{m}}=L_{p} \cdot T M P
$$

where $J_{w}$ is the permeate flux with pure water, $\mu_{w}$ is the pure water viscosity and $R_{m}$ the intrinsic membrane resistance $[47,48]$.

\subsubsection{Estimation of Rejection Coefficient of Agave Fractions}

To estimate the membrane selectivity for each carbohydrate fraction, the solute concentration in permeate stream $\left(C_{p}\right)$ was related to the feed concentration $\left(C_{f}\right)$ through the observed rejection coefficient of the membrane by the following equation [49].

$$
R_{o}=\left(1-\frac{C_{P, i}}{C_{f, i}}\right) \cdot 100 \%
$$

\subsubsection{Analysis of the Fouling Resistance}

To quantify membrane fouling during UF performance, different resistances were calculated. The total resistance of the membrane system $R_{t}$ is the sum of the intrinsic membrane resistance $\left(R_{m}\right)$ plus the fouling resistances $\left(R_{f}\right)$, as expressed in Equation (4) [50].

$$
R_{t}=R_{m}+R_{f}
$$


Thus, the $R_{m}$ was estimated by solving Equation (2), and $R_{t}$ was also calculated from Equation (2), but considering agave fructan solution data as the experimental permeate flux $\left(J_{P}\right)$ and the viscosity of the solution in the permeate stream $\left(\mu_{p}\right)$, which were considered equal to that of water, as it is a dilute solution $(<25 \% \mathrm{w} / \mathrm{v})$ [51,52]. By substituting these considerations into Equation (4), we can obtain the following equation to finally solve $R_{f}$.

$$
R_{f}=\frac{T M P}{\mu_{p} \cdot J_{P}}-R_{m}
$$

where $R_{f}$ represents reversible $\left(R_{e f}\right)$ and irreversible fouling $\left(R_{i f}\right)$. Irreversible fouling was estimated by considering the water permeate flux $\left(J_{f w}\right)$ in Equation (6) at the end of the experiment [53].

$$
R_{i f}=\frac{T M P}{\mu_{w} \cdot J_{f w}}-R_{m}
$$

Therefore, $R_{e f}$ can be obtained by the difference between the $R_{f}$ value obtained from Equation (5) and the $R_{i f}$ value from Equation (6).

\subsubsection{Global Yield of the Process}

The yield of each fraction of agave fructan (i-solute) was calculated as the total quantity recovered in the permeate or concentrate (M2) in relation to the amount present in the feed (M1), expressed as a percentage:

$$
\text { Yield }=\left(\frac{M 2_{i-\text { Solute }}}{M 1_{i-\text { Solute }}}\right) \cdot 100 \%
$$

The purification degree of each agave fructan fraction was calculated as the total quantity recovered in the permeate or concentrate (M2) in relation to the total amount present (M2 total), expressed as a percentage:

$$
\text { Purity }=\left(\frac{M 2_{i-\text { Solute }}}{M 2_{\text {Solute }}^{\text {Total }}}\right) \cdot 100 \%
$$

\subsubsection{Data Analysis}

To verify the difference between both systems, a statistical analysis of variance (ANOVA) of permeate flux and the rejection coefficients was performed, using the Statgraphics centurion XVI software. All the experiments were performed in triplicate.

\section{Results and Discussion}

\subsection{Size Distribution Profile of Agave Fructans}

The carbohydrate distribution of commercial agave fructans was quantified by finding $11.33 \%$ of MD, $23.77 \%$ of FOS and $64.90 \%$ of fructans with DP $>10$, and a size distribution from one to $42 \mathrm{DP}$ (see Figure 3 and Table 2). These results are consistent with the reports of Moreno-Vilet et al. (2017) [44], where the profile of MW changes in the function of the physiological state of maturity of the plant [54]. 
Table 2. Profile of polymerization and mass distribution of commercial agave fructan, obtained with HPLC-SEC analysis.

\begin{tabular}{|c|c|c|c|c|}
\hline DP & Name & Formula & MW kg·kmol-1 & $\%$ \\
\hline 1 & Glucose and Fructose & $\mathrm{C}_{6} \mathrm{H}_{12} \mathrm{O}_{6}$ & 180 & 8.60 \\
\hline 2 & Sucrose & $\mathrm{C}_{12} \mathrm{H}_{22} \mathrm{O}_{11}$ & 342 & 2.73 \\
\hline 3 & Fructose (Fructose) ${ }_{1}$ Glucose & $\mathrm{C}_{18} \mathrm{H}_{32} \mathrm{O}_{16}$ & 504 & 2.30 \\
\hline 4 & Fructose (Fructose) ${ }_{2}$ Glucose & $\mathrm{C}_{24} \mathrm{H}_{42} \mathrm{O}_{21}$ & 666 & 2.43 \\
\hline 5 & Fructose (Fructose) $)_{3}$ Glucose & $\mathrm{C}_{30} \mathrm{H}_{52} \mathrm{O}_{26}$ & 828 & 2.66 \\
\hline 6 & Fructose (Fructose) $)_{4}$ Glucose & $\mathrm{C}_{36} \mathrm{H}_{62} \mathrm{O}_{31}$ & 990 & 2.65 \\
\hline 7 & Fructose (Fructose) $)_{5}$ Glucose & $\mathrm{C}_{42} \mathrm{H}_{72} \mathrm{O}_{36}$ & 1152 & 4.31 \\
\hline 8 & Fructose (Fructose) ${ }_{6}$ Glucose & $\mathrm{C}_{48} \mathrm{H}_{82} \mathrm{O}_{41}$ & 1314 & 3.03 \\
\hline 9 & Fructose (Fructose) $)_{7}$ Glucose & $\mathrm{C}_{54} \mathrm{H}_{92} \mathrm{O}_{46}$ & 1476 & 3.09 \\
\hline 10 & Fructose (Fructose) $)_{8}$ Glucose & $\mathrm{C}_{60} \mathrm{H}_{102} \mathrm{O}_{51}$ & 1638 & 3.29 \\
\hline 11 & Fructose (Fructose) ${ }_{9}$ Glucose & $\mathrm{C}_{66} \mathrm{H}_{112} \mathrm{O}_{56}$ & 1800 & 3.30 \\
\hline 12 & Fructose (Fructose) ${ }_{10}$ Glucose & $\mathrm{C}_{72} \mathrm{H}_{122} \mathrm{O}_{61}$ & 1962 & 3.54 \\
\hline 13 & Fructose (Fructose) ${ }_{11}$ Glucose & $\mathrm{C}_{78} \mathrm{H}_{132} \mathrm{O}_{66}$ & 2124 & 3.58 \\
\hline 14 & Fructose (Fructose) ${ }_{12}$ Glucose & $\mathrm{C}_{84} \mathrm{H}_{142} \mathrm{O}_{71}$ & 2286 & 3.75 \\
\hline 15 & Fructose (Fructose) ${ }_{13}$ Glucose & $\mathrm{C}_{90} \mathrm{H}_{152} \mathrm{O}_{76}$ & 2448 & 3.88 \\
\hline 16 & Fructose (Fructose) ${ }_{14}$ Glucose & $\mathrm{C}_{96} \mathrm{H}_{162} \mathrm{O}_{81}$ & 2610 & 3.95 \\
\hline 17 & Fructose (Fructose) ${ }_{15}$ Glucose & $\mathrm{C}_{102} \mathrm{H}_{172} \mathrm{O}_{86}$ & 2772 & 3.96 \\
\hline 18 & Fructose (Fructose) ${ }_{16}$ Glucose & $\mathrm{C}_{108} \mathrm{H}_{182} \mathrm{O}_{91}$ & 2934 & 3.88 \\
\hline 19 & Fructose (Fructose) ${ }_{17}$ Glucose & $\mathrm{C}_{114} \mathrm{H}_{192} \mathrm{O}_{96}$ & 3096 & 3.71 \\
\hline 20 & Fructose (Fructose) ${ }_{18}$ Glucose & $\mathrm{C}_{120} \mathrm{H}_{202} \mathrm{O}_{101}$ & 3258 & 3.74 \\
\hline 21 & Fructose (Fructose) ${ }_{19}$ Glucose & $\mathrm{C}_{126} \mathrm{H}_{212} \mathrm{O}_{106}$ & 3420 & 3.41 \\
\hline 22 & Fructose (Fructose) ${ }_{20}$ Glucose & $\mathrm{C}_{132} \mathrm{H}_{222} \mathrm{O}_{111}$ & 3582 & 3.29 \\
\hline 23 & Fructose (Fructose) ${ }_{21}$ Glucose & $\mathrm{C}_{138} \mathrm{H}_{232} \mathrm{O}_{116}$ & 3744 & 2.85 \\
\hline 24 & Fructose (Fructose) ${ }_{22}$ Glucose & $\mathrm{C}_{144} \mathrm{H}_{242} \mathrm{O}_{121}$ & 3906 & 2.42 \\
\hline 25 & Fructose (Fructose) ${ }_{23}$ Glucose & $\mathrm{C}_{150} \mathrm{H}_{252} \mathrm{O}_{126}$ & 4068 & 2.43 \\
\hline 26 & Fructose (Fructose) ${ }_{24}$ Glucose & $\mathrm{C}_{156} \mathrm{H}_{262} \mathrm{O}_{131}$ & 4230 & 1.80 \\
\hline 27 & Fructose (Fructose) ${ }_{25}$ Glucose & $\mathrm{C}_{162} \mathrm{H}_{272} \mathrm{O}_{136}$ & 4392 & 1.80 \\
\hline 28 & Fructose (Fructose) ${ }_{26}$ Glucose & $\mathrm{C}_{168} \mathrm{H}_{282} \mathrm{O}_{141}$ & 4554 & 1.44 \\
\hline 29 & Fructose (Fructose) ${ }_{27}$ Glucose & $\mathrm{C}_{174} \mathrm{H}_{292} \mathrm{O}_{146}$ & 4716 & 1.28 \\
\hline 30 & Fructose (Fructose) ${ }_{28}$ Glucose & $\mathrm{C}_{180} \mathrm{H}_{302} \mathrm{O}_{151}$ & 4878 & 1.01 \\
\hline 31 & Fructose (Fructose) ${ }_{29}$ Glucose & $\mathrm{C}_{186} \mathrm{H}_{312} \mathrm{O}_{156}$ & 5040 & 1.01 \\
\hline 32 & Fructose (Fructose) ${ }_{30}$ Glucose & $\mathrm{C}_{192} \mathrm{H}_{322} \mathrm{O}_{161}$ & 5202 & 0.79 \\
\hline 33 & Fructose (Fructose) $)_{31}$ Glucose & $\mathrm{C}_{198} \mathrm{H}_{332} \mathrm{O}_{166}$ & 5364 & 0.71 \\
\hline 34 & Fructose (Fructose) $)_{32}$ Glucose & $\mathrm{C}_{204} \mathrm{H}_{342} \mathrm{O}_{171}$ & 5526 & 0.56 \\
\hline 35 & Fructose (Fructose) ${ }_{33}$ Glucose & $\mathrm{C}_{210} \mathrm{H}_{352} \mathrm{O}_{176}$ & 5688 & 0.58 \\
\hline 36 & Fructose (Fructose) ${ }_{34}$ Glucose & $\mathrm{C}_{216} \mathrm{H}_{362} \mathrm{O}_{181}$ & 5850 & 0.46 \\
\hline 37 & Fructose (Fructose) 35 Glucose & $\mathrm{C}_{222} \mathrm{H}_{372} \mathrm{O}_{186}$ & 6012 & 0.41 \\
\hline 38 & Fructose (Fructose) ${ }_{36}$ Glucose & $\mathrm{C}_{228} \mathrm{H}_{382} \mathrm{O}_{191}$ & 6174 & 0.32 \\
\hline 39 & Fructose (Fructose) 37 Glucose & $\mathrm{C}_{234} \mathrm{H}_{392} \mathrm{O}_{196}$ & 6336 & 0.32 \\
\hline 40 & Fructose (Fructose) ${ }_{38}$ Glucose & $\mathrm{C}_{240} \mathrm{H}_{402} \mathrm{O}_{201}$ & 6498 & 0.27 \\
\hline 41 & Fructose (Fructose) ${ }_{39}$ Glucose & $\mathrm{C}_{246} \mathrm{H}_{412} \mathrm{O}_{206}$ & 6660 & 0.18 \\
\hline \multirow[t]{2}{*}{42} & Fructose (Fructose) $)_{40}$ Glucose & $\mathrm{C}_{252} \mathrm{H}_{422} \mathrm{O}_{211}$ & 6822 & 0.29 \\
\hline & & & Total & 100 \\
\hline
\end{tabular}




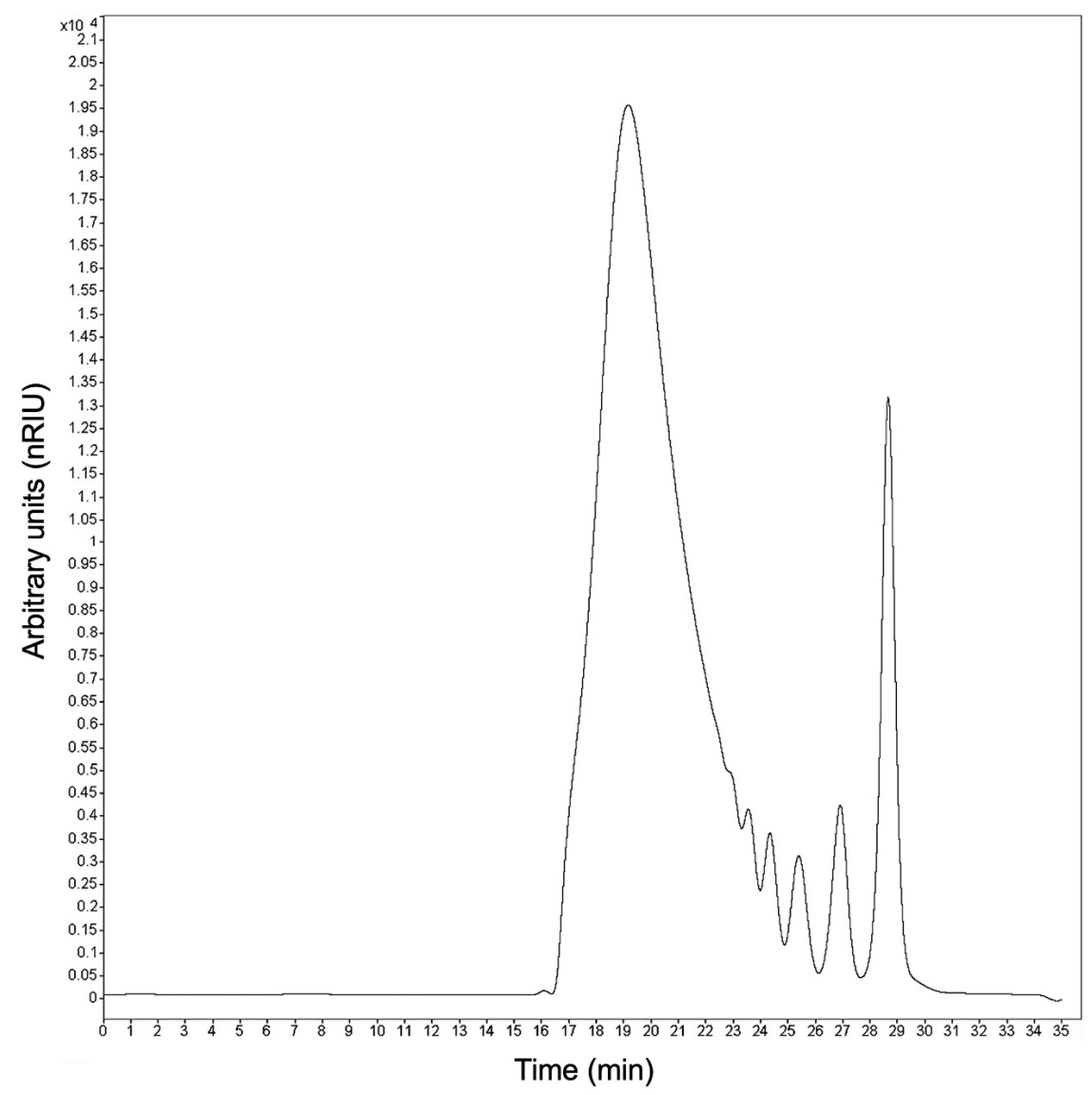

Figure 3. HPLC-size exclusion chromatography (SEC) chromatogram of initial agave fructan sample.

\subsection{Full Recycle Mode Experiments}

\subsubsection{Water Permeability and Permeate Flux of Systems}

To quantify membrane fouling during membrane filtration, it is necessary to know the reference permeate flux by using pure water. This also allows us to guarantee the repeatability of the experiments and the integrity of the membrane. Figure 4 presents the permeate flux as a function of TMP obtained for ceramic and polymeric membrane systems, where the slope that intercepts equal to zero, according to Equation (2), represents the hydraulic permeability. Thus, greatly different hydraulic permeabilities of $L_{p}=9.16 \times 10^{-11} \mathrm{~m}^{2} \cdot \mathrm{s} \cdot \mathrm{kg}^{-1}$ and $L_{p}=1.42 \times 10^{-11} \mathrm{~m}^{2} \cdot \mathrm{s} \cdot \mathrm{kg}^{-1}$ for ceramic and polymeric membrane systems were obtained, respectively. In this sense, for the ceramic membrane, the high value of pure water flux $J_{w}$ at adjusted experimental conditions is also observed, which is attributed to the high estimated tangential velocity of $3 \mathrm{~m} \cdot \mathrm{s}^{-1}$ and high Reynolds number (see Table 3), characteristic of a turbulent flow pattern $(R e>3000)$. In contrast, the polymeric membrane system reached a low pure water flux $J_{w}$ with a tangential velocity of $0.16 \mathrm{~m} \cdot \mathrm{s}^{-1}$ and a Reynolds number characteristic of a laminar flow regimen $(R e<2000)$. These results show the different hydrodynamic conditions reached in each system, despite being membranes of the same MWCO and the same feed flow; these differences can be properly attributed to the configurations of membranes (tubular and spiral-wound), which will have important repercussions, both for the selectivity of solutes and for concentration polarization and fouling. 


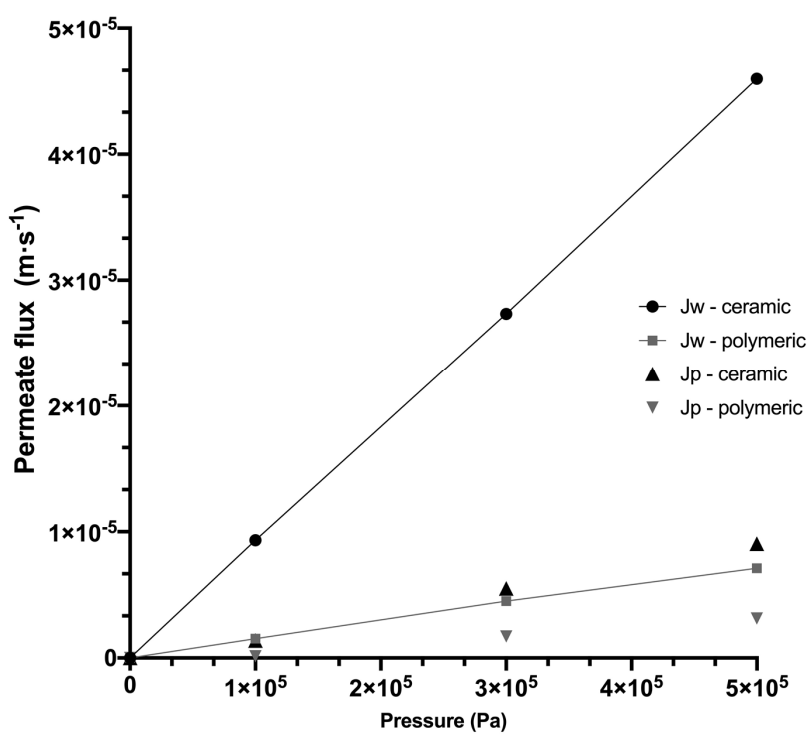

Figure 4. Variation of water flux $\left(J_{w}\right)$ and fructan permeate fluxes with transmembrane pressure for ceramic and polymeric membrane systems, at feed flow of $1.8 \mathrm{~m}^{3} \cdot \mathrm{h}^{-1}$ and $318.15 \mathrm{~K}$.

Table 3. Experimental conditions for the tight ultrafiltration process.

\begin{tabular}{ccc}
\hline Specification & Ceramic Membrane & Polymeric Membrane \\
\hline Operating pressure $(\mathrm{Pa})$ & $3 \times 10^{5}$ & $3 \times 10^{5}$ \\
Tangential velocity $\left(\mathrm{m} \cdot \mathrm{s}^{-1}\right)$ & 3 & 0.16 \\
Reynolds number & 12,460 & 398.74 \\
Operating temperature $(\mathrm{K})$ & 318 & 318 \\
Feed Concentration $\left(\mathrm{kg} \cdot \mathrm{m}^{-3}\right)$ & 100 & 100 \\
Hydraulic diameter $(\mathrm{m})$ & 0.0025 & 0.0015
\end{tabular}

* Data estimated using a $\rho_{s}=990.22 \mathrm{~kg} \cdot \mathrm{m}^{-3}, \mu=596 \times 10^{-6} \mathrm{~kg} \cdot \mathrm{m}^{-1} \cdot \mathrm{s}^{-1}, v=3 \mathrm{~m} \cdot \mathrm{s}^{-1}$ for the ceramic membrane and $v=0.16 \mathrm{~m} \cdot \mathrm{s}^{-1}$ for the polymeric membrane.

During the UF of agave fructan solution, the evolution of the permeate fluxes with TMP follows a behavior similar to that obtained with pure water, but at a lower flux scale, where the differences between both systems are less radical, but maintain a greater flux in the ceramic membrane. The flux drop between pure water and agave solutions was due to the presence of solutes that involve concentration polarization phenomena in the boundary layer of the membrane. Similar results were found by Grangeon and Lescoche (2000) [40] when comparing tubular ceramic membranes with ceramic flat membranes under identical conditions of temperature, TMP and MWCO, where the highest permeate flux was obtained with the tubular membranes, resulting from the highest tangential velocity used. This is also consistent with Cheryan (1998) [55], who reports tangential velocity values of $7 \mathrm{~m} \cdot \mathrm{s}^{-1}$ for ceramic tubular membranes and $1 \mathrm{~m} \cdot \mathrm{s}^{-1}$ for polymeric membranes.

\subsubsection{Rejection Coefficients}

In order to compare the membrane selectivity of both systems (ceramic and polymeric), the rejection coefficient was calculated in three different fractions, grouped by size as fructans with DP $>10$ (MW: 1801.56-5000 kg.kmol ${ }^{-1}$ ), FOS (MW: 504-1639 $\mathrm{kg} \cdot \mathrm{kmol}^{-1}$ ) and MD (MW: 180-342 kg.kmol ${ }^{-1}$ ). Figure 5 shows the observed rejection coefficient of agave fructan fractions for ceramic and polymeric membrane systems, depending on the TMP. For the ceramic membrane system, the rejection values vary, as expected, according to the solute size, as shown in Figure 5a; in general, the rejection of the fractions increased as the TMP increased; this can be attributed to the reduction in pore size caused by the increase in pressure. The lowest rejection coefficients were obtained at the lower TMP of $1 \times 10^{5} \mathrm{~Pa}$ with values of $R_{F C}=68.58 \pm 3.63 \%, R_{F O S}=36.29 \pm 7.66 \%$ and $R_{M D}=21.35 \pm 10.75 \%$. The ceramic 
membrane would be expected to be efficient in the fractionation process since it retains two times more fructans DP > 10 than FOS. These results differ from other studies carried out in the purification process of xylooligosaccharides from liquors of eucalyptus wood and rice husks using the ceramic membrane system [52,56], which reported rejection values of 70 to $93 \%$, which are higher than those found in this work for oligosaccharides; however, it is important to consider that a lot of components are generated during hydrolysis processes such as monosaccharides, acetic acid, oligomers and acetyl groups linked to oligosaccharides, which can interfere with the separation and contribute to the membrane fouling and therefore the greater rejection of solutes.

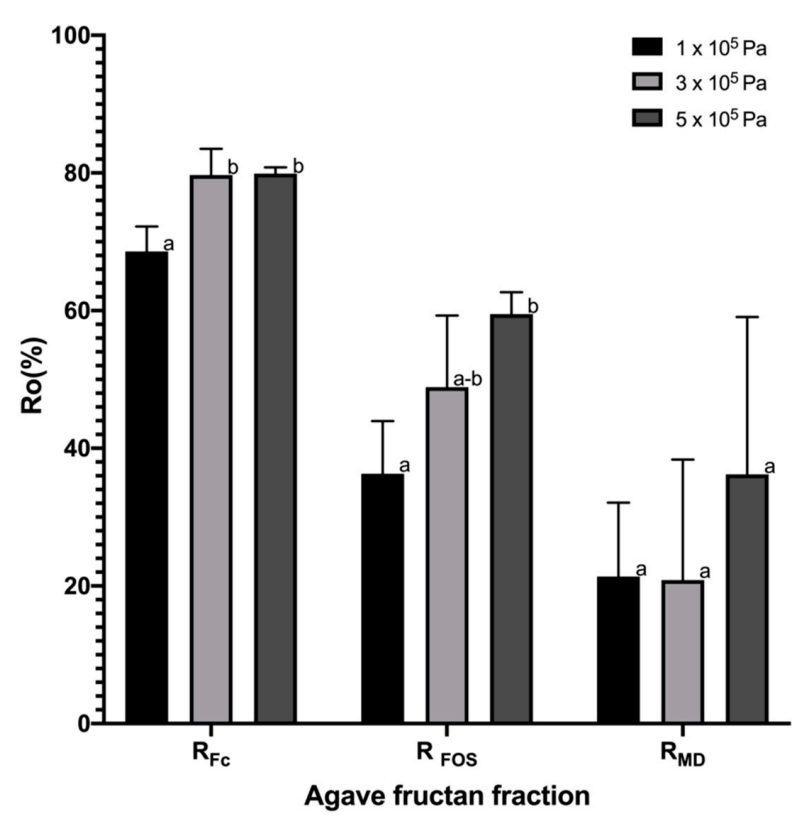

(a)

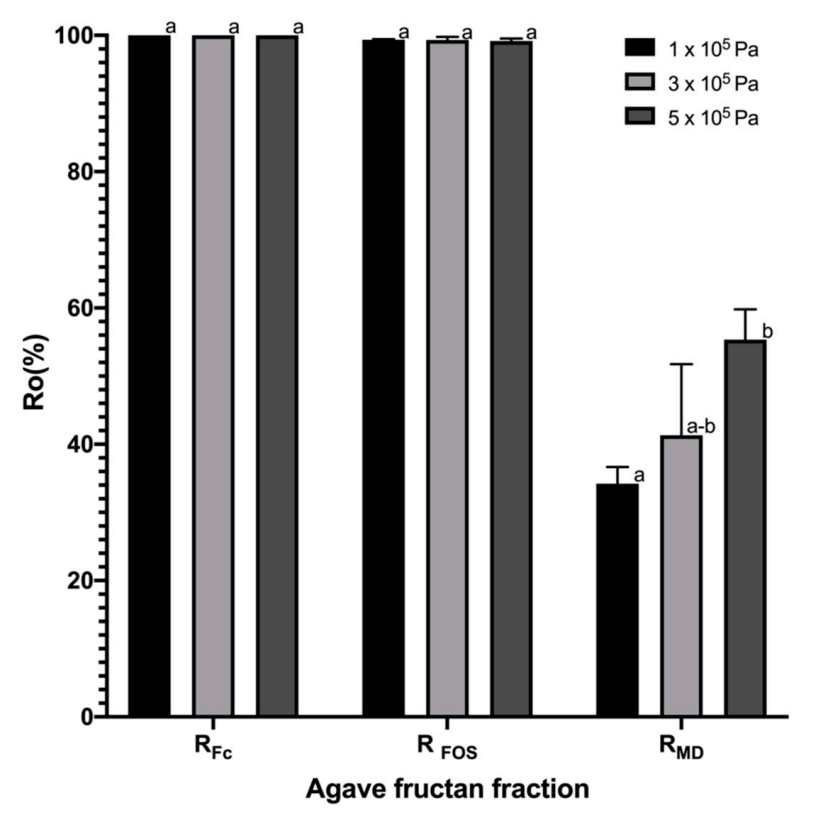

(b)

Figure 5. Observed rejection coefficient of agave fructan fraction: fructans with $\mathrm{DP}>10\left(\mathrm{Fc}_{\mathrm{c}}\right)$, fructooligosaccharides (FOS), mono-disaccharides (MD), using a ceramic membrane system (a) and polymeric membrane system $(\mathbf{b})$ as functions of applied transmembrane pressure. ${ }^{a-b}$ Different superscripts within the same column indicate that the means differ significantly $(p<0.05)$. 
For polymeric membrane systems, bigger rejection coefficients were obtained and are represented in Figure $5 b$, with values of $R_{F C}=100 \pm 0.00 \%, R_{F O S}>99.33 \pm 0.10 \%$ and $R_{M D}>34.22 \pm 2.45 \%$. It is important to note that the polymeric membrane does not have a significant difference between fructans DP $>10$ and FOS rejections, so this would not allow us to carry out an efficient fractionation process. On the other hand, the high rejection found for fructans (considering both fractions), compared to the low rejection of mono- and disaccharides, would make an efficient fructan purification process from this polymeric membrane system. Usually, high rejection values of fructans (considering both fractions, DP $>10+$ FOS) $>90 \%$ have been reported in the literature for polymeric membrane systems $[15,16]$, which is in agreement with the results reported here. Kuhn et al. (2010) [51] report a lower rejection value of $64 \%$ using a spiral polymeric membrane of the same MWCO in the purification of FOS obtained by synthesis. However, this difference can be attributed to the interference produced by fructans with DP > 10 present in agave fructans as a natural source, but not in synthesized ones that avoid the free passage of the middle fractions through the membrane.

Agave fructans are considered neutral charge molecules, so differences in the rejection coefficient can be attributed to the sieving effect, which, in turn, can be directly related to the pore size of the membrane. Since both membranes have the same commercial MWCO of $1 \mathrm{kDa}$, they were expected to have the same pore size. For ceramic membranes of $1 \mathrm{kDa}$, an average pore size of $3 \mathrm{~nm}$ has been estimated [42], while, for a polymeric membrane similar to that used in this study, a polydisperse distribution, in the range from 0.99 to $3.78 \mathrm{~nm}$, has been reported, presenting $50 \%$ of pores with a smaller diameter between 0.99 and $2.12 \mathrm{~nm}$ [43]. The above suggests that the ceramic membrane has a larger pore size than the polymeric one, which can explain the lower rejection coefficient values found.

\subsection{Experiments in Concentration Mode}

\subsubsection{Solute Flux}

The experiments in concentration mode were carried out at $318 \mathrm{~K}, 3 \times 105 \mathrm{~Pa}$ of TMP and a $0.1 \mathrm{~m}^{3}$ feed concentration at $10 \mathrm{~kg} \cdot \mathrm{m}^{-3}$ for both membrane systems. Figure 6 shows the results of the different solute fluxes in the permeate stream during UF performance at different VRF values, where the greatest difference is observed in the flux of major solutes such as Fc and FOS between both systems. As expected, the flux of solute moles was determined according to the molecular weight or size of the molecules, where MD had the highest flux, followed by FOS and, finally, the high-molecular weight fructans, Fc, in both systems. The solute flux in the ceramic membrane (Figure 6a) showed a small decrease in all fraction solutes up to achieving VRF at around 1.42, which is attributed to the concentration polarization and initial pore blocking in the membrane. However, the slopes of permeate curves tend toward a constant around $0.75,0.37$ and 0.1 solute $\mathrm{mol} \cdot \mathrm{h}^{-1} \cdot \mathrm{m}^{-2}$, for MD, FOS and Fc, respectively, from a VRF of 1.42 to the end of the performance. For the polymeric membrane system (Figure $6 \mathrm{~b}$ ), there was no presence of $\mathrm{Fc}_{\mathrm{c}}$ in the permeate, since $100 \%$ is retained by the membrane and the FOS flux $\left(<0.01\right.$ solute $\left.\mathrm{mol} \cdot \mathrm{h}^{-1} \cdot \mathrm{m}^{-2}\right)$ was 45 times less compared to the ceramic system. The MD flux in the polymeric system showed a progressive decrease during the UF performance starting at 0.56 and ending at 0.2 solute $\mathrm{mol} \cdot \mathrm{h}^{-1} \cdot \mathrm{m}^{-2}$. These results show how the hydrodynamic conditions in the systems mainly affect the larger molecules (Fc and FOS), forcing their passage through the ceramic membrane (turbulent flow), but not in the polymeric membrane (laminar flow), while mono- and disaccharides are the smallest solutes with free passage through different membranes. 


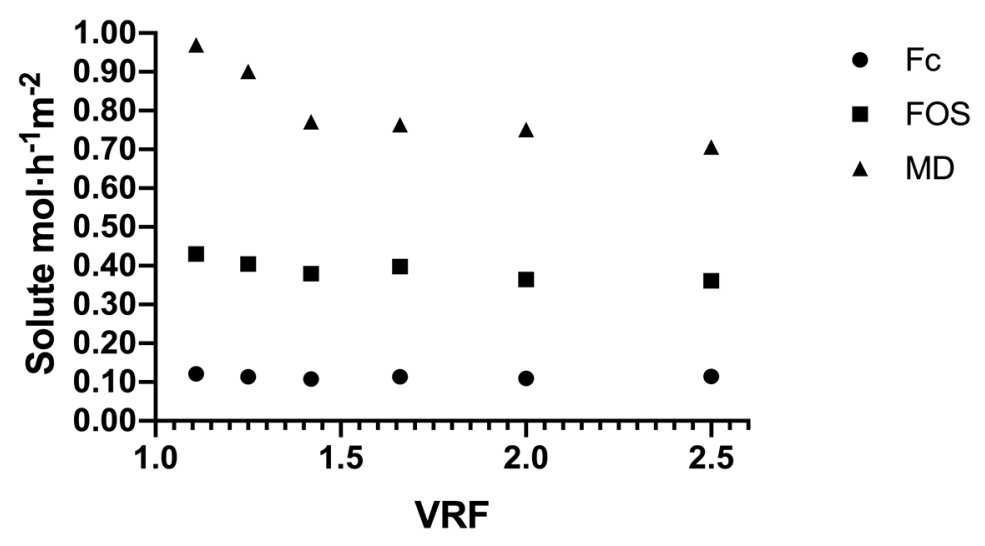

(a)

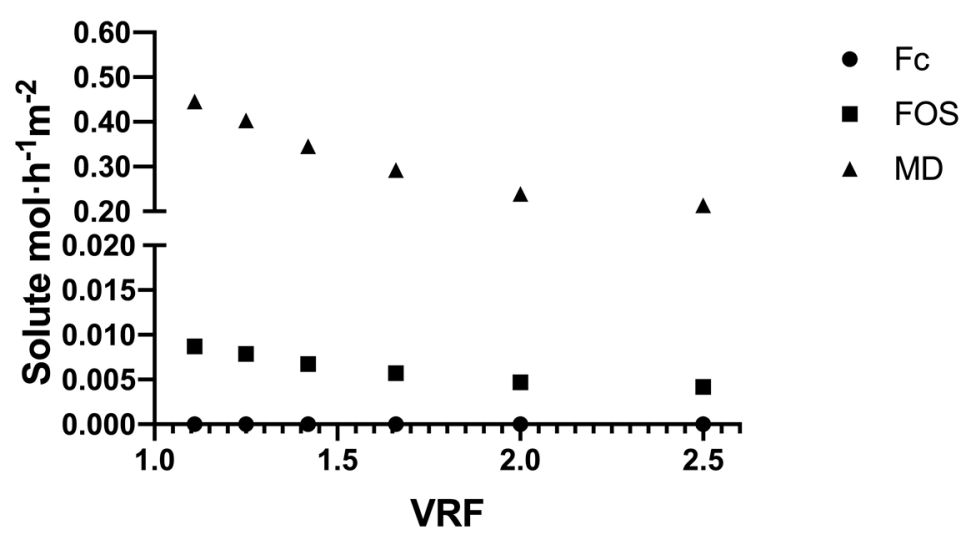

(b)

Figure 6. Time evolution as function of volume reduction factor (VRF) of the permeate flux of different solutes during the tight ultrafiltration process for ceramic membrane (a) and polymeric membrane (b).

\subsubsection{Analysis of the Fouling Resistance}

One of the main drawbacks of membrane technology is the decrease in permeate flux, resulting from the fouling of the membrane, which implies process stoppages and regular cleaning of the membranes. This can be attributed to concentration polarization phenomena and the increase in additional resistance generated by the molecules on the membrane surface and/or pore blocking. Figure 7 shows the calculated values of the resistance from experiments carried out using either ceramic or polymeric membrane systems obtained for a concentration mode when $0.1 \mathrm{~m}^{3}$ solution was treated. For the ceramic membrane system, the intrinsic membrane resistance $R_{m}$ contributes $54.71 \pm 2.16 \%$ of the total resistance, so $30.98 \pm 0.73 \%$ corresponds to the reversible fouling $\left(R_{e f}\right)$, which means that it can be removed using backwash with water. On the other hand, only $14.30 \pm 1.42 \%$ of the fouling corresponds to irreversible fouling, which suggests that few subsequent washes with chemical agents are required to recover the reference flow. In contrast, the polymeric membrane system presents an $R_{m}$ value that corresponds to $48.59 \pm 1.43 \%$ of the total resistance during the experiment with agave fructans, while $49.63 \pm 1.84 \%$ corresponds to reversible fouling $\left(R_{e f}\right)$, meaning that it can be easily removed with rinses, and the weak value of irreversible fouling requires less use of chemicals during the cleaning process, increasing the operational lifetime expectancy of the polymeric membrane. 


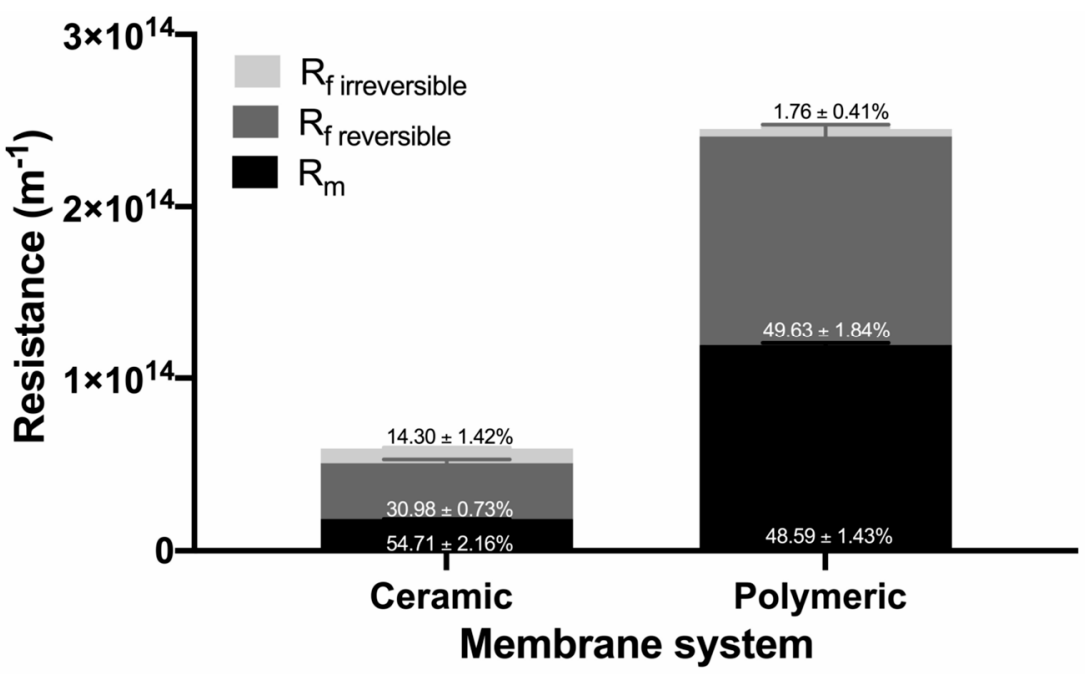

Figure 7. Calculated resistances of the membrane systems—-reversible and irreversible fouling.

Concentration polarization involves the accumulation of solutes in the boundary layer of the membrane that could produce fouling. In this sense, as mentioned before with the Reynolds number in Table 3, a turbulent flow is achieved, using high tangential velocities, which result in a thinner boundary layer and less reversible fouling; therefore, the ceramic membrane is favored over the polymeric membrane in this sense. On the other hand, the molecules could be trapped inside, blocking the pores of the ceramic membrane due to its larger pore size [57], favoring irreversible fouling. In the case of the polymeric membrane, the high percentage of reversible fouling can be explained by the low $R e$ values used in the system (laminar flow), which favor the deposition of particles on the surface of the membrane acting as an additional barrier and favoring solute rejection.

\subsubsection{Analysis of Global Process}

Figure 8 shows the final fructan composition of retentate and permeate in size distribution histograms for both systems. The yield and purity of Fc, FOS, and MD in the retentate and permeate at the end of the total process (concentration mode) were affected according to the membrane system used and the results are reported in Table 4.

Table 4. Global yield of tight ultrafiltration (UF) process with ceramic and polymeric membrane systems.

\begin{tabular}{|c|c|c|c|c|c|c|}
\hline & \multicolumn{3}{|c|}{ Ceramic Membrane System } & \multicolumn{3}{|c|}{ Polymeric Membrane System } \\
\hline Feed solution (kg) & 6.490 & 2.377 & 1.133 & 6.490 & 2.377 & 1.133 \\
\hline $\begin{array}{c}\text { Final yield of the } \\
\text { permeate }(\%)\end{array}$ & $11.05 \pm 3.69^{\mathrm{a}}$ & $40.06 \pm 0.70^{a}$ & $52.08 \pm 1.76^{a}$ & $0.00^{b}$ & $0.98 \pm 0.88^{b}$ & $33.22 \pm 0.79^{b}$ \\
\hline $\begin{array}{l}\text { Purity of the permeate } \\
\qquad(\%)\end{array}$ & $37.05 \pm 2.73^{\mathrm{a}}$ & $42.16 \pm 2.09^{a}$ & $20.78 \pm 0.63^{a}$ & $0.00^{b}$ & $5.87 \pm 2.23^{b}$ & $94.12 \pm 2.23^{b}$ \\
\hline $\begin{array}{l}\text { Purity of the retentate } \\
\qquad(\%)\end{array}$ & $78.23 \pm 0.73^{a}$ & $16.24 \pm 0.62^{a}$ & $5.52 \pm 0.10^{a}$ & $82.38 \pm 0.48^{b}$ & $15.36 \pm 0.28^{a}$ & $2.25 \pm 0.20^{b}$ \\
\hline
\end{tabular}

a-b Different superscripts within the same column of the same fractions between both systems indicate that the means differ significantly $(p<0.05)$.

For the ceramic membrane system (Figure 8a), a wider distribution of fructans in the permeate is obtained with DP in the range of 1-32 and an average DP of 9.1. It means that the FOS fraction was concentrated in a permeate stream with a purity of $42.16 \%$ and a yield of $40.06 \%$, as well as the $50.02 \%$ of MD fraction with $20.78 \%$ of purity, while the Fc fraction reached the highest purity $(78.23 \%)$ in the retentate with a yield of $70.91 \%$, with an average DP of 17.9 . These results confirm the potential use of 
the ceramic membrane system for the fractionation of agave fructans and to obtain a product enriched in FOS in the permeate and a product rich in Fc in the retentate. The FOS obtained can be incorporated into the production of food with a prebiotic effect and the formulation of supplements, while the Fc can be used for its technological properties.

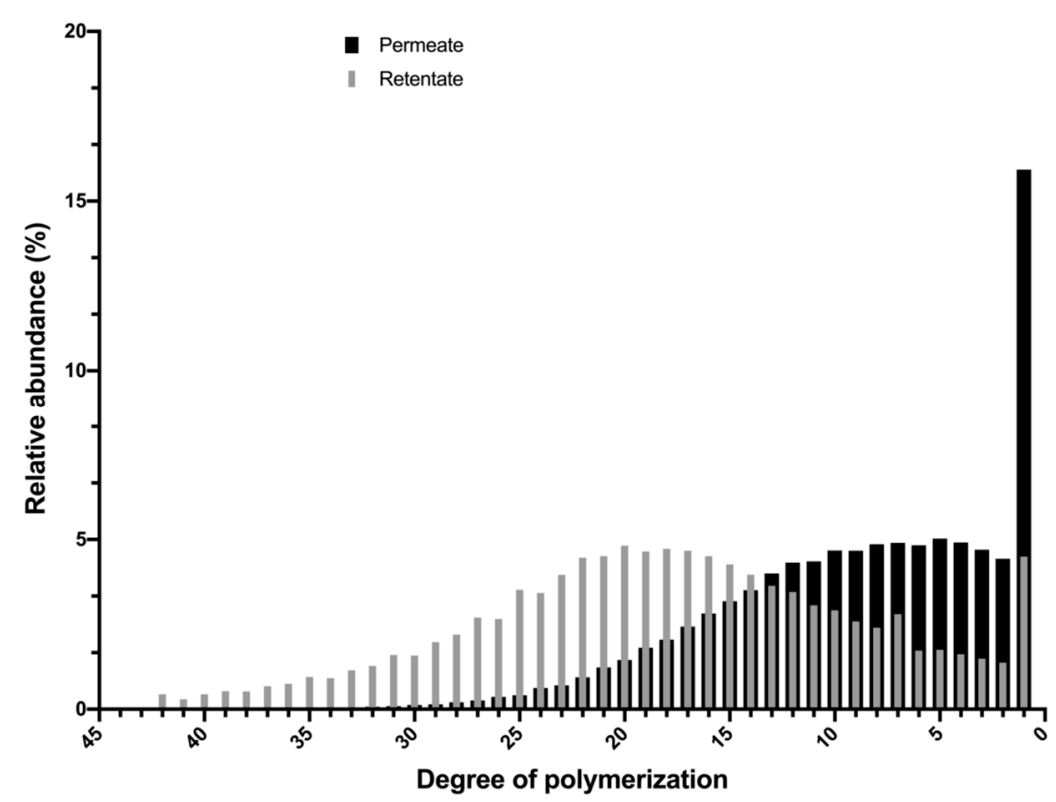

(a)

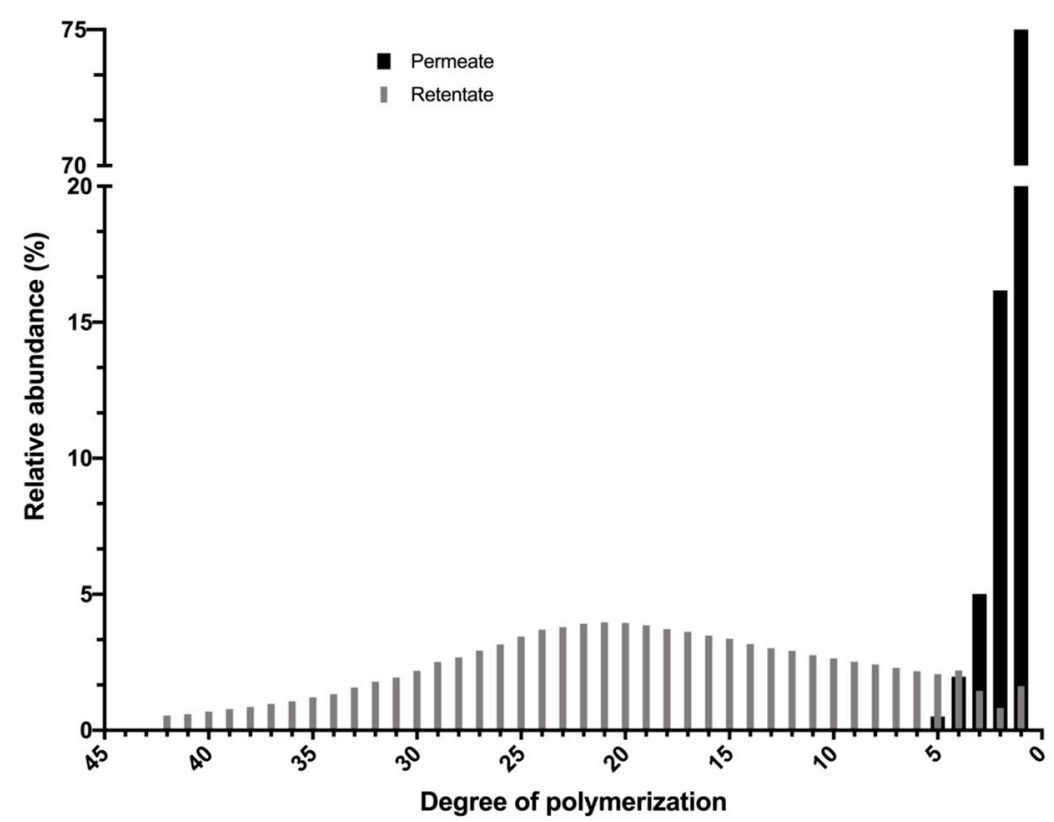

(b)

Figure 8. Fructan size distribution histograms of the final retentate and permeate solutions obtained with ceramic (a) and polymeric (b) membrane systems for a batch process.

For a polymeric membrane system, the cut was more drastic, where the permeate was obtained with a very short distribution of fructans with DP between one and five and average DP of 1.34 (see Figure $8 b$ ). This means that the 33\% MD fraction was recovered from the permeate with a $94 \%$ purity, while $89 \%$ of $\mathrm{FC}$ and $45 \%$ of FOS fractions were recovered in the retentate with a purity of 
$82 \%$ and $15 \%$, respectively, which led to an average DP of 20.69. The low yields obtained from FOS and MD in the polymeric system can be attributed to the deposition of these solutes on the membrane, which can be translated into the large reversible fouling values that this system presented. Experimentally, these solutes were recovered by rinsing the system. These results confirm the potential use of polymeric membranes to obtain a purified product of agave fructans $(\mathrm{Fc}+\mathrm{FOS})$ in the retentate with a purity of $97.74 \%$ and yield of $64.28 \%$, which allows us to improve the techno-functional properties of agave fructans and reduce the difficulties of the drying process associated with the thermoplastic characteristics of low-molecular weight sugars.

Finally, it is important to note that the process times in the concentration mode were $300 \mathrm{~min}$ and $33 \mathrm{~min}$ for the ceramic and polymeric systems, respectively, which were the result of the area of each membrane used.

\section{Conclusions}

Great performance differences were found in our comparison of ceramic and polymeric membrane systems for the tight UF of agave fructans. The hydraulic permeability, permeate flux and rejection coefficient were affected by the membrane type and TMP, using the same temperature, feed concentration and MWCO of membranes for both systems, where the ceramic membrane system presented higher hydraulic permeability and permeate flux, but also greater irreversible fouling compared to the polymeric membrane. The hydrodynamic conditions defined by the configuration and material of the membrane, independently of MWCO, largely define the pattern of solute separation and fouling during a performance, so they are important conditions to consider in future works. The global yield of the process results in very different permeation patterns between both systems at the same operational conditions. Therefore, the membranes studied can be used for different purposes; the ceramic membrane system could be used to fractionate agave fructans and thus obtain products with different MW profiles, while the polymeric membrane system could be used for purification, meaning monoand disaccharide-free agave fructans.

Author Contributions: Conceptualization, N.L.-S., R.P.-R. and L.M.-V.; methodology, N.L.-S. and R.-M.C.-R.; software, N.L.-S.; validation, N.L.-S. and R.-M.C.-R.; formal analysis, N.L.-S., R.-M.C.-R. and L.M.-V.; investigation, R.P.-R. and E.A.-G.; resources, L.M.-V. and R.P.-R.; data curation, N.L.-S. and L.M.-V.; writing-original draft preparation, N.L.-S. and L.M.-V.; writing-review and editing, R.P.-R., R.M.C.R., and E.A.-G.; visualization, L.M.-V. and R.P.-R.; supervision, R.P.-R. and E.A.-G.; project administration, L.M.-V.; funding acquisition, R.P.-R., R.-M.C.-R. and L.M.-V. All authors have read and agreed to the published version of the manuscript.

Funding: The authors are thankful for the financial support of the project SEP-CONACYT 287926, México.

Acknowledgments: N. Luiz-Santos thanks CONACYT for the doctoral fellowship (No. 340380).

Conflicts of Interest: The authors declare no conflict of interest.

\section{Nomenclature}

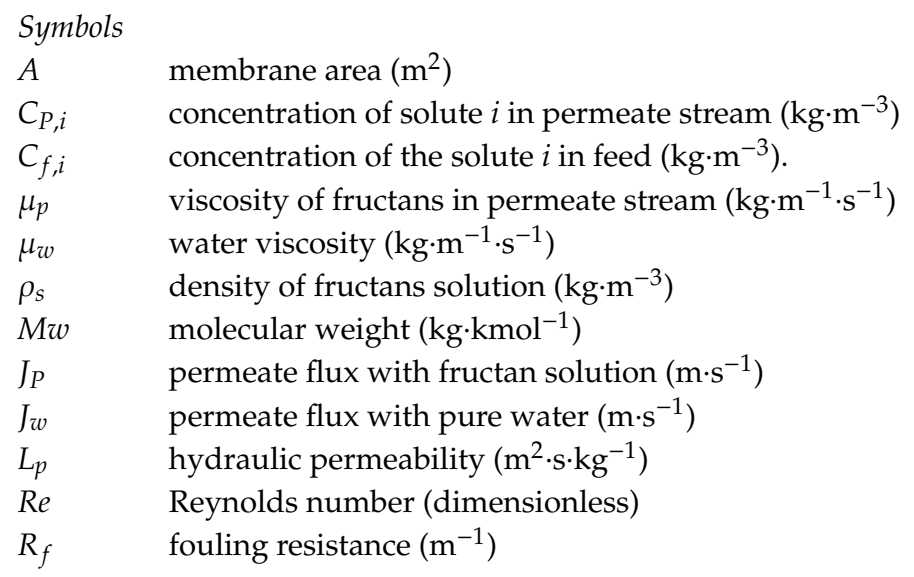




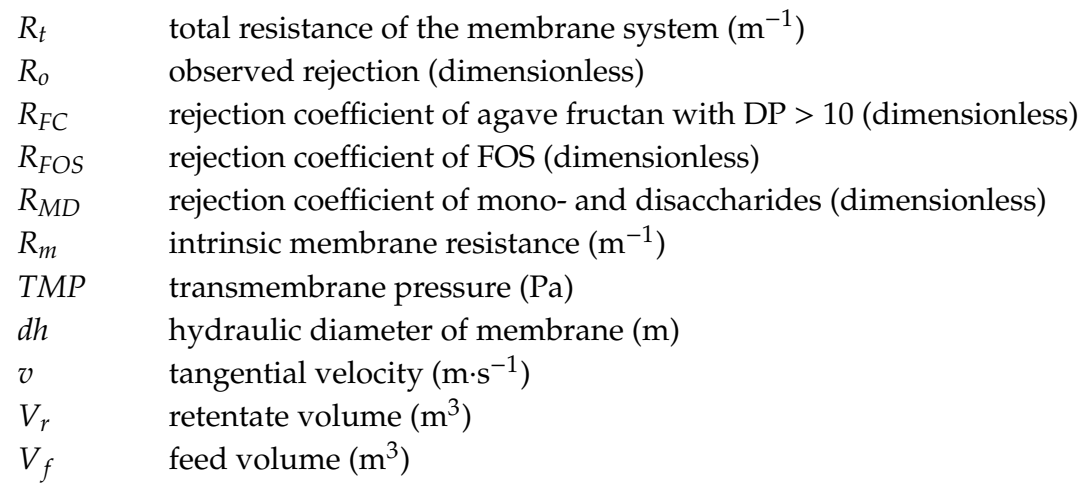

\section{References}

1. Lopez, M.G.; Mancilla-Margalli, N.A.; Mendoza-Díaz, G. Molecular Structures of Fructans from Agave tequilana Weber var.azul. J. Agric. Food Chem. 2003, 51, 7835-7840. [CrossRef]

2. Urías-Silvas, J.E.; Cani, P.D.; Delmée, E.; Neyrinck, A.; López, M.G.; Delzenne, N.M. Physiological effects of dietary fructans extracted from Agave tequilana Gto. and Dasylirion spp. Br. J. Nutr. 2008, 99, $254-261$. [CrossRef]

3. Sáyago-Ayerdi, S.G.; Mateos, R.; Ortiz-Basurto, R.I.; Largo, C.; Serrano, J.; Granado-Serrano, A.B.; Sarriá, B.; Bravo, L.; Tabernero, M. Effects of consuming diets containing Agave tequilana dietary fibre and jamaica calyces on body weight gain and redox status in hypercholesterolemic rats. Food Chem. 2014, 148, 54-59. [CrossRef]

4. Ramnani, P.; Costabile, A.; Bustillo, A.G.R.; Gibson, G.R. A randomised, double- blind, cross-over study investigating the prebiotic effect of agave fructans in healthy human subjects. J. Nutr. Sci. 2015, 4, 1-10. [CrossRef]

5. Padilla-Camberos, E.; Barragán-Álvarez, C.P.; Diaz-Martinez, N.E.; Rathod, V.; Flores-Fernández, J.M. Effects of Agave fructans (Agave tequilana Weber var. azul) on Body Fat and Serum Lipids in Obesity. Plant Foods Hum. Nutr. 2018, 73, 34-39. [CrossRef]

6. Crispín-Isidro, G.; Lobato-Calleros, C.; Espinosa-Andrews, H.; Alvarez-Ramirez, J.; Vernon-Carter, E.J. Effect of inulin and agave fructans addition on the rheological, microstructural and sensory properties of reduced-fat stirred yogurt. LWT Food Sci. Technol. 2015, 62, 438-444. [CrossRef]

7. Palatnik, D.R.; Aldrete Herrera, P.; Rinaldoni, A.N.; Ortiz Basurto, R.I.; Campderrós, M.E. Development of reduced-fat cheeses with the addition of Agave fructans. Int. J. Dairy Technol. 2017, 70, 212-219. [CrossRef]

8. Ortiz-Basurto, R.I.; Rubio-Ibarra, M.E.; Ragazzo-Sanchez, J.A.; Beristain, C.I.; Jiménez-Fernández, M. Microencapsulation of Eugenia uniflora L. juice by spray drying using fructans with different degrees of polymerisation. Carbohydr. Polym. 2017, 175, 603-609. [CrossRef]

9. Santiago-García, P.A.; Mellado-Mojica, E.; León-Martínez, F.M.; López, M.G. Evaluation of Agave angustifolia fructans as fat replacer in the cookies manufacture. LWT Food Sci. Technol. 2017, 77, 100-109. [CrossRef]

10. Jimenez-Sánchez, D.E.; Calderón-Santoyo, M.; Ortiz-Basurto, R.I.; Bautista-Rosales, P.U.; Ragazzo-Sánchez, J.A. Effect of maltodextrin reduction and native agave fructans addition on the physicochemical properties of spray-dried mango and pineapple juices. Food Sci. Technol. Int. 2018, 24, 519-532. [CrossRef] [PubMed]

11. Márquez-Aguirre, A.L.; Camacho-Ruiz, R.M.; Arriaga-Alba, M.; Padilla-Camberos, E.; Kirchmayr, M.R.; Blasco, J.L.; González-Avila, M. Effects of Agave tequilana fructans with different degree of polymerization profiles on the body weight, blood lipids and count of fecal Lactobacilli/Bifidobacteria in obese mice. Food Funct. 2013, 4, 1237-1244. [CrossRef] [PubMed]

12. Márquez-Aguirre, A.L.; Camacho-Ruíz, R.M.; Gutiérrez-Mercado, Y.K.; Padilla-Camberos, E.; González-Ávila, M.; Gálvez-Gastélum, F.J.; Díaz-Martínez, N.E.; Ortuño-Sahagún, D. Fructans from Agave tequilana with a Lower Degree of Polymerization Prevent Weight Gain, Hyperglycemia and Liver Steatosis in High-Fat Diet-Induced Obese Mice. Plant Foods Hum. Nutr. 2016, 71, 416-421. [CrossRef] 
13. García Gamboa, R.; Ortiz Basurto, R.I.; Calderón Santoyo, M.; Bravo Madrigal, J.; Ruiz Álvarez, B.E.; González Avila, M. In vitro evaluation of prebiotic activity, pathogen inhibition and enzymatic metabolism of intestinal bacteria in the presence of fructans extracted from agave: A comparison based on polymerization degree. LWT Food Sci. Technol. 2018, 92, 380-387. [CrossRef]

14. Moreno-Vilet, L.; Moscosa-Santillán, M.; Grajales-Lagunes, A.; González-Chávez, M.; Bonnin-Paris, J.; Bostyn, S.; Ruiz-Cabrera, M. Sugars and Fructans Separation by Nanofiltration from Model Sugar Solution and Comparative Study with Natural Agave Juice. Sep. Sci. Technol. 2013, 48, 1768-1776. [CrossRef]

15. Moreno-Vilet, L.; Bonnin-Paris, J.; Bostyn, S.; Ruiz-Cabrera, M.A.; Moscosa-Santillán, M. Assessment of sugars separation from a model carbohydrates solution by nanofiltration using a design of experiments (DoE) methodology. Sep. Purif. Technol. 2014, 131, 84-93. [CrossRef]

16. Reynoso-Ponce, H.; Grajales-Lagunes, A.; Castillo-Andrade, A.; González-García, R.; Ruiz-Cabrera, M.A. Integration of nanofiltration and spray drying processes for enhancing the purity of powdered fructans from Agave salmiana juice. Powder Technol. 2017, 322, 96-105. [CrossRef]

17. Pérez Martínez, F.J.; Gonzalez Avila, M.; Camacho Ruiz, R.M.; Márquez Aguirre, A.L.; Alonso Segura, D.; Gschaedler Mathis, A.C.; Prado Ramírez, R.; Flores Montaño, J.L.; Mateos Díaz, J.C.; Arrizón Gaviño, J.P. Fructanos Fraccionados de Agave, Proceso de Obtención y uso de los Mismos. MX Patent 367976 B, 30 April 2013.

18. Flores Montaño, J.L.; Camacho Ruiz, R.M.; Prado Ramírez, R.; Morena Vilet, L.; Luiz Santos, N.; Mendoza Rivera, M.; de los, Á.; Ballón Villagrá, A. Fructanos Fraccionados de Agave y su Proceso de Obtención a Nivel Piloto e Industrial. Patent request MX/a/2015/014523, 15 October 2015.

19. Fane, A.G.; Tang, C.Y.; Wang, R. Membrane Technology for Water: Microfiltration, Ultrafiltration, Nanofiltration, and Reverse Osmosis. Treatise Water Sci. 2010, 4, 301-335. [CrossRef]

20. Cassano, A.; Conidi, C.; Ruby-Figueroa, R.; Castro-Muñoz, R. Nanofiltration and tight ultrafiltration membranes for the recovery of polyphenols from agro-food by-products. Int. J. Mol. Sci. 2018, 19, 351. [CrossRef]

21. Shang, R.; Verliefde, A.R.D.; Hu, J.; Zeng, Z.; Lu, J.; Kemperman, A.J.B.; Deng, H.; Nijmeijer, K.; Heijman, S.G.J.; Rietveld, L.C. Tight ceramic UF membrane as RO pre-treatment: The role of electrostatic interactions on phosphate rejection. Water Res. 2014, 48, 498-507. [CrossRef]

22. Aguirre Montesdeoca, V.; Janssen, A.E.M.; Boom, R.M.; Van der Padt, A. Fine ultrafiltration of concentrated oligosaccharide solutions-Hydration and pore size distribution effects. J. Memb. Sci. 2019, 580, 161-176. [CrossRef]

23. Singh, R. Introduction to Membrane Technology. In Membrane Technology and Engineering for Water Purification, 2nd ed.; Elsevier Ltd.: Amsterdam, The Netherlands, 2015; pp. 1-80. [CrossRef]

24. Liu, Y.; Wei, W.; Wang, X.; Yang, H.; Xie, Y.F. Relating the rejections of oligomeric ethylene glycols and saccharides by nanofiltration: Implication for membrane pore size determination. Sep. Purif. Technol. 2018, 205, 151-158. [CrossRef]

25. Mora, F.; Pérez, K.; Quezada, C.; Herrera, C.; Cassano, A.; Ruby-Figueroa, R. Impact of membrane pore size on the clarification performance of grape marc extract by microfiltration. Membranes 2019, 9, 146. [CrossRef]

26. Hu, K.; Dickson, J.M.; Kentish, S.E. Microfiltration for casein and serum protein separation. In Membrane Processing for Dairy Ingredient Separation, 1st ed.; Hu, K., Dickson, J.M., Eds.; Jonh Wiley \& Sons, Ltd.: Hoboken, NJ, USA, 2015; pp. 1-34. [CrossRef]

27. Gitis, V.; Rothenberg, G. The basics. In Ceramic Membranes: New Opportunities and Practical Applications, 1st ed.; Wiley-VCH Verlag GmbH \& Co. KGaA.: Weinheim, Germany, 2016; pp. 1-395. [CrossRef]

28. Urošević, T.; Povrenović, D.; Vukosavljević, P.; Urošević, I.; Stevanović, S. Recent developments in microfiltration and ultrafiltration of fruit juices. Food Bioprod. Process. 2017, 106, 147-161. [CrossRef]

29. Teng, J.; Wu, M.; Chen, J.; Lin, H.; He, Y. Different fouling propensities of loosely and tightly bound extracellular polymeric substances (EPSs) and the related fouling mechanisms in a membrane bioreactor. Chemosphere 2020, 255, 126953. [CrossRef] [PubMed]

30. Rao, L.; Tang, J.; Hu, S.; Shen, L.; Xu, Y.; Li, R.; Lin, H. Inkjet printing assisted electroless Ni plating to fabricate nickel coated polypropylene membrane with improved performance. J. Colloid Interface Sci. 2020, 565, 546-554. [CrossRef] [PubMed] 
31. Wu, M.; Chen, Y.; Lin, H.; Zhao, L.; Shen, L.; Li, R.; Xu, Y.; Hong, H.; He, Y. Membrane fouling caused by biological foams in a submerged membrane bioreactor: Mechanism insights. Water Res. 2020, 181, 115932. [CrossRef] [PubMed]

32. Liu, Y.; Shen, L.; Lin, H.; Yu, W.; Xu, Y.; Li, R.; Sun, T.; He, Y. A novel strategy based on magnetic field assisted preparation of magnetic and photocatalytic membranes with improved performance. J. Memb. Sci. 2020, 612, 118378. [CrossRef]

33. Sun, T.; Liu, Y.; Shen, L.; Xu, Y.; Li, R.; Huang, L.; Lin, H. Magnetic field assisted arrangement of photocatalytic $\mathrm{TiO} 2$ particles on membrane surface to enhance membrane antifouling performance for water treatment. Colloid Interface Sci. 2020, 570, 273-285. [CrossRef]

34. Li, R.; Fan, H.; Shen, L.; Rao, L.; Tang, J.; Hu, S.; Lin, H. Inkjet printing assisted fabrication of polyphenol-based coating membranes for oil/water separation. Chemosphere 2020, 250, 126236. [CrossRef]

35. Alresheedi, M.T.; Barbeau, B.; Basu, O.D. Comparisons of NOM fouling and cleaning of ceramic and polymeric membranes during water treatment. Sep. Purif. Technol. 2019, 209, 452-460. [CrossRef]

36. Lee, S.J.; Dilaver, M.; Park, P.K.; Kim, J.H. Comparative analysis of fouling characteristics of ceramic and polymeric microfiltration membranes using filtration models. J. Memb. Sci. 2013, 432, 97-105. [CrossRef]

37. Karasu, K.; Glennon, N.; Lawrence, N.D.; Stevens, G.W.; O'connor, A.J.; Barber, A.R.; Yoshikawa, S.; Kentish, S.E. A comparison between ceramic and polymeric membrane systems for casein concentrate manufacture. Int. J. Dairy Technol. 2010, 63, 284-289. [CrossRef]

38. Dudziak, M.; Wyczarska-Kokot, J.; Łaskawiec, E.; Stolarczyk, A. Application of ultrafiltration in a swimming pool water treatment system. Membranes 2019, 9, 44. [CrossRef] [PubMed]

39. Abd-Razak, N.H.; Chew, Y.M.J.; Bird, M.R. Membrane fouling during the fractionation of phytosterols isolated from orange juice. Food Bioprod. Process. 2019, 113, 10-21. [CrossRef]

40. Grangeon, A.; Lescoche, P. Flat ceramic membranes for the treatment of dairy products: Comparison with tubular ceramic membranes. Le Lait. 2000, 80, 5-14. [CrossRef]

41. Siddiqui, A.; Lehmann, S.; Haaksman, V.; Ogier, J.; Schellenberg, C.; van Loosdrecht, M.C.M.; Kruithof, J.C.; Vrouwenvelder, J.S. Porosity of spacer-filled channels in spiral-wound membrane systems: Quantification methods and impact on hydraulic characterization. Water Res. 2017, 119, 304-311. [CrossRef]

42. Chevereau, E.; Zouaoui, N.; Limousy, L.; Dutournié, P.; Déon, S.; Bourseau, P. Surface properties of ceramic ultrafiltration $\mathrm{TiO} 2$ membranes: Effects of surface equilibriums on salt retention. Desalination 2010, 255, 1-8. [CrossRef]

43. Schmidt, C.M.; Sprunk, M.; Löffler, R.; Hinrichs, J. Relating nanofiltration membrane morphology to observed rejection of saccharides. Sep. Purif. Technol. 2020, 239, 116550. [CrossRef]

44. Moreno-Vilet, L.; Bostyn, S.; Flores-Montaño, J.L.; Camacho-Ruiz, R.M. Size-exclusion chromatography (HPLC-SEC) technique optimization by simplex method to estimate molecular weight distribution of agave fructans. Food Chem. 2017, 237, 833-840. [CrossRef]

45. Ávila-Fernández, Á.; Rendón-Poujol, X.; Olvera, C.; González, F.; Capella, S.; Peña-Alvarez, A.; López-Munguía, A. Enzymatic hydrolysis of fructans in the tequila production process. J. Agric. Food Chem. 2009, 57, 5578-5585. [CrossRef]

46. Ávila-Fernández, Á.; Galicia-Lagunas, N.; Rodríguez-Alegría, M.E.; Olvera, C.; López-Munguía, A. Production of functional oligosaccharides through limited acid hydrolysis of agave fructans. Food Chem. 2011, 129, 380-386. [CrossRef] [PubMed]

47. Evans, P.J.; Bird, M.R. Solute-membrane fouling interactions during the ultrafiltration of black tea liquor. Food Bioprod. Process. 2006, 84, 292-301. [CrossRef]

48. Macedo, A.; Duarte, E.; Fragoso, R. Assessment of the performance of three ultrafiltration membranes for fractionation of ovine second cheese whey. Int. Dairy J. 2015, 48, 31-37. [CrossRef]

49. Nair, R.R.; Protasova, E.; Strand, S.; Bilstad, T. Implementation of spiegler-Kedem and steric hindrance pore models for analyzing nanofiltration membrane performance for smart water production. Membranes 2018, 8 , 78. [CrossRef] [PubMed]

50. Acero, J.L.; Benitez, F.J.; Real, F.J.; García, C. Removal of phenyl-urea herbicides in natural waters by UF membranes: Permeate flux, analysis of resistances and rejection coefficients. Sep. Purif. Technol. 2009, 65, 322-330. [CrossRef]

51. Kuhn, R.C.; Maugeri Filho, F.; Silva, V.; Palacio, L.; Hernández, A.; Prádanos, P. Mass transfer and transport during purification of fructooligosaccharides by nanofiltration. J. Memb. Sci. 2010, 365, 356-365. [CrossRef] 
52. González-Muñoz, M.J.; Parajó, J.C. Diafiltration of Eucalyptus wood autohydrolysis liquors: Mathematical modeling. J. Memb. Sci. 2010, 346, 98-104. [CrossRef]

53. Muthukumaran, S.; Nguyen, D.A.; Baskaran, K. Performance evaluation of different ultrafiltration membranes for the reclamation and reuse of secondary effluent. Desalination 2011, 279, 383-389. [CrossRef]

54. Arrizon, J.; Morel, S.; Gschaedler, A.; Monsan, P. Comparison of the water-soluble carbohydrate composition and fructan structures of Agave tequilana plants of different ages. Food Chem. 2010, 122, 123-130. [CrossRef]

55. Cheryan, M. Ultrafiltration and Microfiltration Handbook; Technomic Publishing Company, Inc.: Lancaster, PA, USA, 1998.

56. Vegas, R.; Moure, A.; Domínguez, H.; Parajó, J.C.; Alvarez, J.R.; Luque, S. Evaluation of ultra- and nanofiltration for refining soluble products from rice husk xylan. Bioresour. Technol. 2008, 99, 5341-5351. [CrossRef]

57. Cassano, A.; Marchio, M.; Drioli, E. Clarification of blood orange juice by ultrafiltration: Analyses of operating parameters, membrane fouling and juice quality. Desalination 2007, 212, 15-27. [CrossRef]

(C) 2020 by the authors. Licensee MDPI, Basel, Switzerland. This article is an open access article distributed under the terms and conditions of the Creative Commons Attribution (CC BY) license (http://creativecommons.org/licenses/by/4.0/). 